\title{
Study of Information Communication Technology and Economic Growth Performance in Southeast Asian Countries
}

\author{
Muhamad Ferdy Firmansyah"*, Muhammad Ihsaan Rizqulloh', Haikal Zulian Maulana² \\ ${ }^{I}$ Department of Economic Development, Faculty Economics and Business, Universitas Siliwangi, Indonesia \\ ${ }^{2}$ Department of Accounting, Faculty Economics and Business, Universitas Siliwangi, Indonesia \\ *Corresponding author E-mail: muhamadferdy77@gmail.com
}

Manuscript received 23 Feb 2021; revised 2 March. 2021; accepted 15 March 2021. Date of publication 2 April 2021

\begin{abstract}
Information and communication technology is a set of tools or technology which in terminology includes all technical tools for processing and also disclosing informationInformation and communication technology, including media technology, has been growing in the era of globalization. The development of this technology has an impact on changes in people's behavior in the use of mass media and in the end also changes the pattern of effective community development in the digital era as it is today. The development of information and communication technology has brought many changes to human life in the world. Humans are able to penetrate time and space by using technology based on information and communication technology. This study uses secondary data obtained from the World Bank Indocator and the International Telecommunication Union. The method used is a quantitative method with panel data regression from 2010-2019 in eight Southeast Asian countries namely Brunei, Cambodia, Indonesia, Malaysia, Singapore, Philippines, Thailand and Vietnam. The variables used in this study are Economic Growth, ICT Trade Export, ICT Trade Import, Landline Telephone, Mobile Phone, Internet Users, Internet Secure Servers, Fixed Broadband, and Foreign Direct Investment. This study forms three models, namely model 1 for research on Trade Export of ICT, model 2 for research on Trade Import of ICT and model 3 for research on Economic Growth and ICT. The results showed that model 1 found only Fixed Broadband which had a significant influence on ICT exports. In model 2 there are Mobile Phone and Fixed Boradband which have a significant influence on the import of ICT. While in model 3 only Foreign Direct Investment has a significant influence on economic growth.
\end{abstract}

Keywords: Technology, Information, Communication, Economic Growth, Development.

\section{Introduction}

Southeast Asian countries consist of a number of peninsula, mainland and island countries. The countries located on the peninsula and mainland Asia are Myanmar, Thailand, Laos, Cambodia, Vietnam and Malaysia. While the countries that are included in the archipelago such as Indonesia, Singapore, Brunei, and the Philippines. Every country in Southeast Asia has an economic structure that is still developing (except Singapore and Brunei, which have high per capita incomes so they are considered prosperous countries). With an economic structure that is still developing, there are a number of different characteristics driving economic growth in each country. Like Indonesia, Malaysia and Thailand which have good developments in the industrial world, on the other hand countries such as Laos and Cambodia which have good development in agriculture. while in some countries, such as Singapore, promoting tourism, banking and health aspects as driving aspects of economic growth. Economic growth is a macroeconomic measure that can show overall economic performance. This is because economic growth is measured by each addition and subtraction of all sectors classified as economic transaction activities. Economic growth can explain the prosperity of a country and sectoral activities that are presented both in local and national data banking and health as the driving aspects of economic growth. Economic growth is a macroeconomic measure that can show overall economic performance. This is because economic growth is measured by each addition and subtraction of all sectors classified as economic transaction activities. Economic growth can explain the prosperity of a country and sectoral activities that are presented both in local and national data banking and health as the driving aspects of economic growth. Economic growth is a macroeconomic measure that can show overall economic performance. This is because economic growth is measured by each addition and subtraction of all sectors classified as economic transaction activities. Economic growth can explain the prosperity of a country and sectoral activities that are presented both in local and national data[1]. In the development of technological adaptation, which has begun to be massive, the ICT sector has become one of the driving factors for economic growth in the era of globalization. The possible influence of ICT to influence economic growth is driven by the many adaptations of technology in people's lives and economic activities, such as in the fields of business, education, 
health and government[2][3]. The existence of this adaptation allows for a new productivity

transformation of each sector that shifts from manual work adaptation to technological automation.

Information and communication technology (hereinafter referred to as ICT) is a set of tools or technology which in terminology includes all technical tools for processing and also disclosing information [4]. In a broader sense, information technology has a close relationship in a series of processes, the use of tools and manipulation efforts in managing information. Technology in its development can also include systems, organizations, and also related to technical matters. The application of ICT is very broad in people's lives and can be a supporting factor in human capital development [5]. In business, ICT is used as a set of tools to support business processes that occur in companies, both in finance, management and economics. There are a number of examples for the application of ICT in the business world, such as the development of e-business, e-commerce, e-banking and others. Managerically, the application of ICT in the business world can also change a work norm, which is true in the development of Enterprise Resources Planning (ERP) implementation. In the field of education, the transformation and adaptation of technology that is developing in the world of education provides an overview of changes in learning media from face-to-face to ICT-based ones. In the application of ICT, it can be seen from the development of learning technology. In its application in everyday life, learning carried out with a combination of ICT media is often referred to as Electronic Learning (E-Learning). E-learning is developing in the world of education in the use of audio/data, video/data, audio/video media and also the use of internetbased learning. In education, students and teachers can be able to interact with each other without having to do face-to-face classes, but it can be done using online learning media and other e-learning systems. This makes learning for a student not limited by distance or time. In the health sector, the application of ICT has begun to be applied in the pattern of medical interpreters which are usually used to evaluate a patient's medical history, make online complaints via the internet and even a smart card system that is used as part of knowing an individual's recorded health performance. In more advanced development, the use of robots has begun to be used in the world of health such as in the identification of diseases, research and the use of personal computers to identify body parts. Furthermore, in the field of government, the application of ICT has long been used in the interests of community social databases, In tourism, ICT can be used in imaging a number of studies that require location mapping in analyzing mapped economic benefits or mapping for the benefit of renewable energy [6][7]. Furthermore, in the use of a number of paid and free streaming services, ICT has transformed from ordinary internet services to streaming services that broadly have specific marketing strategies [8] [9]. The development of ICT in the realm of tourism and streaming services has proven that ICT developments have contributed to the growth of other strategic sectors.

Information and communication technology as a potential force as capital and land in a country [3] [10]. The 19th century was the century of capital. Whoever controls capital, he will control various lines in government, business, and society. Entering the 20th century, a shift began to occur when the information and communication technology revolution became an important part of the lives of many people. Thus, a new paradigm emerges that mastering ICT means also mastering the livelihoods of the wider community. In fact, the mastery does not only serve the community,but also directs people to certain targets. Modern society that depends on ICT can no longer be free because it has been bound by arrangements made based on software applications that make work easier and faster. Further developments in the field of information technology (information technology) and other communications is the rapid development of processors (chips) that function as the brain of a personal computer (Personal Computer). The development of hardware technology is also followed by progress in the field of software, although its development is far behind the development of hardware. Initially, the processor and software were designed for a stand-alone personal computer (stand alone PC). However, in line with its development, The PC can finally be integrated through a network (network) physically. So now we know various types of networks that integrate multiple PCs. Examples of networks that are often used are local area network (LAN), wide area network (WAN), intranet, internet, wireless, and others. The internet network is one type of network that is popularly used, because the internet is an information technology that is able to connect computers around the world, thus enabling information from various types and forms of information to be used together.

The discovery of the effect of economic growth influenced by ICT is found in BRICS countries (Brazil, Russia, China and South Africa) with mobile phone and fixed broadband being two important factors [11] [12]. For developed countries, technological adaptation has been accompanied by good research and development support so that economic growth is really one of the reasons supported by ICT [13]. In Africa, ICT has a significant effect on economic growth by being influenced by the mobile phone subscriber variable and the need for large investments in technological adaptation [14][15]. In India the development of ICT can affect economic growth in increasing the productivity of the use of ICT, so the development of the ICT industry needs to be supported in order to increase the service sector that supports economic growth [16]. With the rapid development of ICT that is able to affect economic growth, in fact, every country needs to support further developments in the adoption of automation and technology supported by administrative procedures and policies [17][18] [9]. This study aims to find factors in information and communication technology that can affect economic growth. The variables used as independent variables are ICT Trade Export, ICT Trade Import, Composite Index of Information and Communication Technology (ICT), Landline Telephone, Mobile Phone, Internet Users, Internet Secure Servers, Fixed Broadband, and Foreign Direct Investment. And the dependent variable in this study is economic growth. This research focuses on how ICT trade affects economic growth but in general it still carries a number of major components of measuring the performance of technology adaptation and automation which includes the Composite Index of Information and Communication Technology (ICT) [19] [20].

\section{Literature Review}

\subsection{International Trade}

The development of theory regarding international trade develops over a long period of time. In the basic theory, international trade can be distinguished from two theories, namely classical country-based theories and modern firm-based theories. In classical country-based theories, there are a number of theoretical backgrounds based on differences in development time. In mercantilist theory (16th century) the country should increase it's holdings of gold and silver by promoting exports and discouraging imports (protectionism). After the mercantilis developed as one of the paradigms in international trade, appeared in 1776 an economist by the name of Adam Smith who issued a book entitled "the wealth of nations: an inquiry into the nature and causes of the wealth and nations". Adam Smith argues that the ability of a country to produce a good more efficiently than another nation. In 1817 a figure by the name of David Ricardo developed a theory in international trade by issuing the concept of "comparative advantage" which stated that when a country cannot produce a product more efficiently than other countries. However, it can produce that product better and more efficiently than it does other goods. The development of classical country-based theories developed until the 1990s where Eli Heckscher and Bertil Ohlin issued a famous opinion on the "Heckscher-Ohlin Theory" or better known as the Factor Proportions Theory which states that a country could gain comparative advantage by producing products that utilized factors that were in abundance in the country such as labor, 
In another development based on a theoretical approach in modern firm-based theories, first stated by Steffan Linder in 1961 which was given the name "Country Similarity Theory", he stated that intra-industrial trade-consumer in countries that are in the same or similar stage of development would have similar preferences. That is would be the companies first produce for domestic consumption. When they explore exporting, the companies often find that markets that look similar to their domestic one, in terms of customer preferences, offer the most potential for success. Furthermore, the development of theories regarding international trade in modern firm-based theories developed "Product Life Cycle Theory" which was developed in the 1960s by Raymond Vernon. He said that a product life cycle has three distinct states: (1) new product, (2) maturing product, and (3) standardized product. The theory assumed that the production of the new product will occur completely in the home country of its innovation. The next development in international trade theory was in the 1980s where Paul Krugman and Kelvin Lancaster argued in the "Global Strategic Rivalry Theory" theory which stated the barriers to entry refer to the obstacles a new firm may face when trying to enter into an industry or new market. , which are tried to gain by MNCs (Multi National Companies).

\subsection{ICT and Components Variable}

Economic growth has a number of aspects that can support it, among these aspects is the use of ICT in people's lives. A society that has a level of technological literacy and technological adaptation in daily life characterizes a country that is modern and intellectual. Following the possibility of the influence of ICT on economic growth, measurements can be made through a conceptual growth model approach that has the potential to explain the supporting variables of ICT itself (such as international trade) [21]. ICT in the development of data collection has a number of components that are usually categorized as ICT, so if we focus on a number of components of information technology funds, there are landline telephones, mobile phones, internet users, internet secure servers and fixed broadband. Of these five components, these components can be part of the development of the ICT sector in its contribution to sectors for economic growth, on the other hand, by supporting value, this component is a supporter for efforts to automate and digitize a number of other sectors such as business, education, health and government.

\subsection{ICT and Economic Growth}

In Knowing the relationship of ICT development to economic growth can be seen through three basic ways. First, ICT from goods and services (YICT) which is one part of the value added that collects economic structural growth. In this regard, the development of ICT can be divided into two value added, namely (1) being a separate sector that contributes to the field of ICT, and (2) being a supporting value for other sectors. In support of a separate sector, it is often classified as part of the value added through the activities of the ICT industry, consumption of ICT and several other ICT sectors which are classified as activities in the ICT sector. Furthermore, if ICT is seen as part of the supporting value to other sectors, then technological adaptation is considered to encourage a number of sectors to develop. This can be identified from the existence of policy moments such as the start of modernization in agriculture through government regulations and budgets, so a number of sectors in the year after the implementation of the policy will be assumed as part of the contribution of ICT in the growth of the sector.

\subsection{Production Approcah}

In understanding the impact of ICT on economic growth from the above descriptions of theories and assumptions, a production approach can be used to form a model. The amount of production output is determined by the amount of capital and labor[22][23]. Mathematically, the Cobb-Douglas production function is as follows:

$Y=c K^{\alpha} L^{1-\alpha}$

With the following information:

$\begin{array}{lll}Y & : & \text { Amount of output value (production result) } \\ K & : & \text { Amount of capital } \\ L & : & \text { Number of workers } \\ c & : & \text { Production efficiency } \\ \alpha \text { and }(1-\alpha)=\beta & : & \text { The elasticity of each factor of production }\end{array}$

The Cobb-Douglas production function can be applied to describe the state of the economy of a country. Therefore, the Cobb-Douglas production function can be applied to describe the state of a country's economy and the contribution of ICT in it, this modeling still represents capital, labor and output [24]. Therefore, the Cobb-Douglas production function which has been written in equation above, is given the following assumptions:

a. Capital $(\mathrm{K})$, which is the total cost incurred to produce a good and service in this modeling uses the realization of domestic investment and the realization of foreign investment (PMLN). $\mathrm{K}$ in this function is assumed to be the total amount of investment, investment from these two sources which will finance the production of national goods and services, especially in the non-oil and gas processing industry sector.

b. Labor $(\mathrm{L})$ is a number of individuals who have productivity and become a factor of production as well as an input in the CobbDouglas production function model. In this case, data on population aged 15 years and over by main occupation is used. The total amount of the working workforce and the percentage change each year in the 2009-2018 period is used. Work is an activity to earn income to meet basic needs in carrying out life.

c. The output value of the output (production output; Y) is the total goods or services produced and in this case is assumed to be the Gross Domestic Product. In utilizing inputs (realization of domestic investment and foreign investment, as well as the number of absorptions of the working labor force), the measure of GDP growth is the result of the production activities of the two inputs used in this function.

d. Score $\alpha$ is the elasticity of the realization of domestic investment and the realization of foreign investment.

e. Score $1-\alpha=\beta$ is the elasticity of labor.

In following the conceptual framework of the Cobb-Douglas equation, a growth model can be formed that represents the contribution of ICT as an explanatory variable, with the following equation[25]:

$Y_{i t}=Y\left(Y_{i t}^{I C T}, Y_{i t}^{0}\right)=A_{i t} F\left(C_{i t}, K_{i t}, H_{i t}, N_{i t}\right)$ 
Where it explains I is a sector unit, $\mathrm{t}$ is a time unit. $\mathrm{Y}$ is total value added, YICT is added value of goods and services related to ICT, and Y0 represents value added related to other products. Production is possible through ICT inputs (C) and non-ICT inputs. As for following the Cobb-Douglass equation, the productivity of $\mathrm{Y}$ can be influenced by physical capital $(\mathrm{K})$, human capital $(\mathrm{H})$ and labor force $(\mathrm{N})$.

\section{Methods}

In measuring the estimation of the influence of a number of ICT factors on economic growth in Southeast Asia, it is necessary to collect data, estimation techniques and assumptions used as the basis for conducting research. The data used in this study is secondary data originating from internet sources for data providers such as the International Telecommunication Union, and World Bank Indicators. The data collection technique used is to access a number of secondary data provider pages. The variables used in this study are the independent variables, namely ICT Trade Export, ICT Trade Import, Landline Telephone, Mobile Phone, Internet Users, Internet Secure Servers, Fixed Broadband, and Foreign Direct Investment.

Table 1. Description of Variables, Symbols and Data Source

\begin{tabular}{|c|c|c|c|}
\hline Variable & Symbols & Description & Data Sources \\
\hline ICT Trade Export & TR & $\begin{array}{l}\text { the action of selling goods and services in } \\
\text { Information and Communication Technology }\end{array}$ & $\begin{array}{l}\text { World Bank Indicators, World } \\
\text { Bank }\end{array}$ \\
\hline ICT Trade Import & TRI & $\begin{array}{l}\text { the action of buying goods and services in } \\
\text { Information and Communication Technology }\end{array}$ & $\begin{array}{l}\text { World Bank Indicators, World } \\
\text { Bank }\end{array}$ \\
\hline Telephone Landline & LLTE & $\begin{array}{l}\text { It is a device with a physical line connection to a } \\
\text { telecommunications network. }\end{array}$ & $\begin{array}{l}\text { World Bank Indicators, World } \\
\text { Bank }\end{array}$ \\
\hline Mobile Phone & MOBP & $\begin{array}{l}\text { It is a telephone with access to a cellular radio } \\
\text { system so it can be used over a wide area, without } \\
\text { a physical connection to a network. }\end{array}$ & $\begin{array}{l}\text { World Bank Indicators, World } \\
\text { Bank } \\
\text { International } \\
\text { Telecommunication Union, } \\
\text { ITU }\end{array}$ \\
\hline Internet Users & INTU & $\begin{array}{l}\text { It is the number of people accessing the internet, } \\
\text { usually expressed as a proportion of the } \\
\text { population. }\end{array}$ & $\begin{array}{l}\text { World Bank Indicators, World } \\
\text { Bank }\end{array}$ \\
\hline Internet Secure Servers & INSS & $\begin{array}{l}\text { those servers that use the secure sockets layer } \\
\text { protocol to protect communication from } \\
\text { unintended recipients. More commonly referred to } \\
\text { as SSL servers, secure servers will communicate } \\
\text { between other Web servers and Web browsers } \\
\text { using cryptography, or encrypted and decrypted } \\
\text { communication. }\end{array}$ & $\begin{array}{l}\text { World Bank Indicators, World } \\
\text { Bank }\end{array}$ \\
\hline Fixed Broadband & FIXB & $\begin{array}{l}\text { Fixed broadband includes any high-speed data } \\
\text { transmission to a residence or a business - ie a } \\
\text { fixed location - using a variety of technologies, } \\
\text { including cable, DSL, fiber optics, and wireless. } \\
\text { Essentially, it refers to high-speed internet } \\
\text { connections that are "always on" in fixed } \\
\text { locations. }\end{array}$ & $\begin{array}{l}\text { World Bank Indicators, World } \\
\text { Bank } \\
\text { International } \\
\text { Telecommunication Union, } \\
\text { ITU }\end{array}$ \\
\hline Economic Growth & PGDP & $\begin{array}{l}\text { It is an increase in the production of economic } \\
\text { goods and services, compared from one period of } \\
\text { time to another. It can be measured in nominal or } \\
\text { real (adjusted for inflation) terms. }\end{array}$ & $\begin{array}{l}\text { World Bank Indicators, World } \\
\text { Bank }\end{array}$ \\
\hline Foreign Direct Investment & FDI & $\begin{array}{l}\text { It is an investment made by a firm or individual } \\
\text { in one country into business interests located in } \\
\text { another country. }\end{array}$ & $\begin{array}{l}\text { World Bank Indicators, World } \\
\text { Bank }\end{array}$ \\
\hline
\end{tabular}

In conducting research estimates, this study uses a quantitative method approach by using panel data regression estimates. As for the object of research is a Southeast Asian country that has complete data in a number of required data as shown in the table above. As for the panel data regression estimation, it is necessary to test the feasibility of the model by first approaching the best model from the Common Effect Model (CEM), Fixed Effect Model (FEM) and Random Effect Model (REM). Hypothesis testing in this study using an individual t-test approach is used to test the effect of each independent variable on the dependent variable, and the F-test to test all independent variables on the dependent variable.

\subsection{Panel Data}

Panel Data Regression is a combination of cross section data and time series data, where the same cross section unit is measured at different times. So in other words, panel data is data from the same individuals who are observed over a certain period of time. If we have $\mathrm{T}$ time periods $(t=1,2, \ldots, T)$ and $\mathrm{N}$ number of individuals $(\mathrm{i}=1,2, \ldots, \mathrm{N})$, then with panel data we will have a total of NT units of observation. If the number of time units is the same for each individual, then the data is called a balanced panel. If, on the other hand, the number of units of time is different for each individual, it is called an unbalanced panel [26].

In the econometric method using panel data, we recognize the determination of the best model using the Common Effect Model (CEM), Fixed Effect Model (FEM) and Random Effect Model (REM) approaches. 
a. Common Effect Model (CEM)

This first approach is the simplest approach which is called CEM estimation or pooled least square. According to Sukendar and Zainal (2007), in this approach it is assumed that the intercept value of each variable is the same, as well as the slope coefficients for all crosssection and time series units. Based on this assumption, the CEM model is stated as follows

$y_{i t}=\alpha+\beta^{\prime} X_{i t}+u_{i t}$

b. Fixed Effect Model (FEM)

According to Gujarati (2004), one way to pay attention to the cross-sectional unit in the panel regression model is to allow different intercept values for each cross-sectional unit but still assume a fixed coefficient slope. The FEM model can be expressed as follows:

$y_{i t}=\alpha_{i}+\beta^{\prime} X_{i t}+u_{i t}$

Model (3) is known as the Fixed Effect model because although the intercept is different for each cross-sectional unit, this intercept is not different or constant for each time series unit (time invariant).

c. Random Effect Model (BRAKE)

In the REM model, it is assumed that $i$ is a random variable with a mean of 0 . so that the intercept can be expressed as $i=0+i$ where $\mathrm{i}$ is a random error that has a mean 0 and a variance $2, \mathrm{i}$ is not directly observed or is also called a latent variable. So the equation of the random effect model is as follows[26]:

$y_{i t}=\alpha_{i}+\beta^{\prime} X_{i t}+u_{i t}$

With $\mathrm{a}=\mathrm{E}$, the residual component of the sector unit is assumed to be random and has an IID distribution $\left(0_{x} \sigma_{v}^{2}\right)$ and uncorrelated with each other, and uncorrelated with xit. vit is the combined residual component of the unit of time. The sector unit is an error that is stochastic and independently distributed and identical with a mean of 0 and a variance $\sigma_{\varepsilon}^{2}$. Ui is assumed to be independent of vit, and Xit is assumed to be independent of ui and vit. So wit $=i+u i t$. The combined error term wit contains two error components, namely $i$ the cross section error component and uit which is a combination of cross section and time series error components. Because of this, the random effects model is often called the Error Components Model (ECM).

As for selecting the model in the panel data, it is used to select the best model in the estimation of the panel data test. The tests used are the Chow test, Hausman test and the Lagrange multiplier test. Chow test is used to determine whether the FEM model is better than the CEM model. The Chow test tested the significance of the intercept, whether it was different in each sector (FEM) or not (CEM). The hypotheses used in determining the selection of the model are as follows:

Ho $\quad: \alpha_{1}=\alpha_{1}=\cdots \alpha_{k}=\alpha$ (CEM models)

$\mathrm{Ha} \quad:$ there is at least one intercept $\alpha_{i} \neq \alpha(\mathrm{FEM}$ modelsi=I,2,.., $\mathrm{K} ; \mathrm{t}=1,2, \ldots, \mathrm{T}$

Hausman test is used to determine which model is better between FEM and REM models. An important element in this selection method is the covariance matrix of the difference vector $(b-\beta)$, i.e. $\operatorname{Var}[b-\beta]=\operatorname{Var}[b]+\operatorname{Var}[\beta]-\operatorname{Cov}[b-\beta]-\operatorname{Cov}[b-\beta][26]$. Where $b$ is the parameter (without intercept) of REM and $\operatorname{Cov} \beta$ is the FEM parameter using LSDV. Var[b] is a parameter covariance matrix (without intercept) REM and $\operatorname{Var}[\beta]$ is the FEM parameter covariance matrix. The value of the Hausman statistic will follow a chi-square distribution with degrees of freedom $\mathrm{P}$, where $\mathrm{P}$ is the number of independent variables. Hausman testing was performed on the eit of the REM model. The hypothesis used in this test is as follows:

Ho $\quad: \operatorname{corr}($ Xit, eit $)=0($ REM model $)$

Ha $\quad: \operatorname{corr}($ Xit, eit $) \neq 0$ (FEM models); $\mathrm{i}=\mathrm{I}, 2, \ldots, \mathrm{K} ; \mathrm{t}=1,2, \ldots, \mathrm{T}$

The lagrange multiplier test is used to choose a better model between CEM and REM, by conducting REM testing based on the residual value of REM. The hypotheses used are as follows:

Ho $\quad: \sigma_{\varepsilon}^{2}=0$ (CEM model)

Ha $\quad: \sigma_{\varepsilon}^{2} \neq 0$ (REM model); $\mathrm{i}=\mathrm{I}, 2, \ldots, \mathrm{K} ; \mathrm{t}=1,2, \ldots, \mathrm{T}$

\subsection{Modeling}

The model used in this study refers to the panel data equation model with the Cobb-Douglas function approach to reflect the dependent variable that is part of the factors supporting the concept of productivity in economic growth. The modeling is as follows:

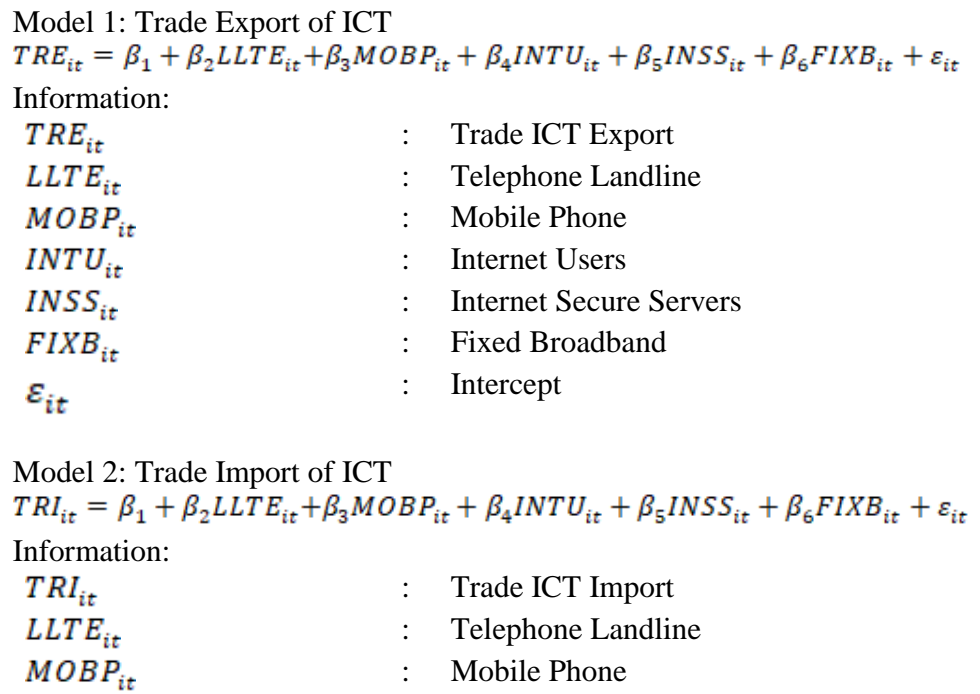

Information:

$T R E_{i}$

$L L T E_{\text {it }}$

$M O B P_{i t}$

$I N T U_{i t}$

INSS $_{\text {it }}$

$F I X B_{i t}$

Model 2: Trade Import of ICT

$T R I_{i t}=\beta_{1}+\beta_{2} L L T E_{i t}+\beta_{3} M O B P_{i t}+\beta_{4} I N T U_{i t}+\beta_{5} I N S S_{i t}+\beta_{6} F I X B_{i t}+\varepsilon_{i t}$

Information:

$L L T E_{i t}$

$M O B P_{i t}$

Telephone Landline

Mobile Phone 


$\begin{array}{lll}I N T U_{i t} & : & \text { Internet Users } \\ I N S S_{i t} & : & \text { Internet Secure Servers } \\ \text { FIXB }_{\text {it }} & : & \text { Fixed Broadband } \\ \varepsilon_{\text {it }} & : & \text { Intercept }\end{array}$

Model 3: Economic Growth and ICT

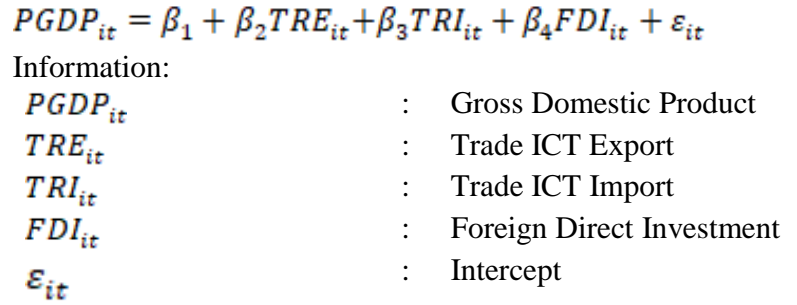

\section{Results and Discussion}

\subsection{Model Selection Data Panel}

Model A: Trade Export of ICT

As for determining the best model used for estimation in model A (trade export of ICT), the chow test and hausman test approaches are used. The Chow test is used to estimate the comparison between the CEM and FEM models, while the Hausman test is used to estimate the comparison between the FEM or REM models. Here is a test.

Table 2. Chow Test

\begin{tabular}{cccc}
\hline Effects Test & Statistics & df & Prob. \\
\hline Cross-section F & 103.043938 & $(7.67)$ & 0.0000 \\
Cross-section Chi-square & 197.215656 & 7 & 0.0000 \\
\hline
\end{tabular}

In determining the chow test, a chi-square cross-sectional approach can be used. Found prob value. of cross-section chi-square is 0.0000 so that the selected model is the fixed effect model. After having a fixed effect model, then it is then tested with the Hausman test with the following results:

Table 3. Hausman Test

\begin{tabular}{cccc}
\hline Test Summary & $\begin{array}{c}\text { Chi-Sq. } \\
\text { Statistics }\end{array}$ & Chi-Sq. df & Prob. \\
\hline Cross-section random & 1.836976 & 5 & 0.8712 \\
\hline
\end{tabular}

In determining the results of the Hausman test, a random cross-sectional approach was used. Found prob value. from a random crosssection with a value of 0.8712 so that the selected model is a random effect model. Therefore, the Lagrangian multiplier test is then used to determine the REM or CEM model.

Table 4. Lagrange Multiplier (LM) Test

\begin{tabular}{cccc}
\hline \multirow{2}{*}{ Test Summary } & Cross-section & One-sided & \multirow{2}{*}{ Both } \\
& On-sided & period & \\
\hline \multirow{2}{*}{ Breusch-Pagan } & 55.17388 & 0.200164 & 55.37404 \\
& $(0.0000)$ & $(0.6546)$ & $(0.0000)$ \\
\hline
\end{tabular}

In determining the results of the Lagrange multiplier test, the Breusch-Pagan approach is used. Found the value of prob. which is 0.0000 so that the selected model is a random effect model. The conclusion is that model A for trade export of ICT uses a random effect model in its value estimation.

Model B: Trade Import of ICT

As for determining the best model used for estimation on model A (trade import of ICT), the chow test and hausman test approaches are used. The Chow test is used to estimate the comparison between the CEM and FEM models, while the Hausman test is used to estimate the comparison between the FEM or REM models. Here is a test.

Table 5. Chow Test

\begin{tabular}{cccc}
\hline Effects Test & Statistics & df & Prob. \\
\hline Cross-section F & 85.865202 & $(7.67)$ & 0.0000 \\
Cross-section Chi-square & 183.974400 & 7 & 0.0000 \\
\hline
\end{tabular}

In determining the chow test, a chi-square cross-sectional approach can be used. Found prob value. of cross-section chi-square is 0.0000 so that the selected model is the fixed effect model. After having a fixed effect model, then it is then tested with the Hausman test with the following results:

Table 6. Hausman Test

\begin{tabular}{cccc}
\hline Test Summary & $\begin{array}{c}\text { Chi-Sq. } \\
\text { Statistics }\end{array}$ & Chi-Sq. df & Prob. \\
\hline Cross-section random & 2.609530 & 5 & 0.7599 \\
\hline
\end{tabular}


In determining the results of the Hausman test, a random cross-sectional approach was used. Found prob value. from a random crosssection with a value of 0.7599 so that the selected model is a random effect model. Therefore, the Lagrangian multiplier test is then used to determine the REM or CEM model.

Table 7. Lagrange Multiplier (LM) Test

\begin{tabular}{cccc}
\hline Test Summary & $\begin{array}{c}\text { Cross-section } \\
\text { On-sided }\end{array}$ & $\begin{array}{c}\text { One-sided } \\
\text { period }\end{array}$ & Both \\
\hline \multirow{2}{*}{ Breusch-Pagan } & 222.7386 & 0.780589 & 223.5192 \\
& $(0.0000)$ & $(0.3770)$ & $(0.0000)$ \\
\hline
\end{tabular}

In determining the results of the Lagrange multiplier test, the Breusch-Pagan approach is used. Found the value of prob. which is 0.0000 so that the selected model is a random effect model. The conclusion is that model A for the trade import of ICT uses a random effect model in the estimation of its value.

Model C: Economic Growth and ICT

As for determining the best model used for estimation in model $\mathrm{C}$ (economic growth and ICT), the chow test and hausman test approaches are used. The Chow test is used to estimate the comparison between the CEM and FEM models, while the Hausman test is used to estimate the comparison between the FEM or REM models. Here is a test.

Table 8. Chow Test

\begin{tabular}{cccc}
\hline Effects Test & Statistics & df & Prob. \\
\hline Cross-section F & 12.728087 & $(7.69)$ & 0.0000 \\
Cross-section Chi-square & 66.327982 & 7 & 0.0000 \\
\hline
\end{tabular}

In determining the chow test, a chi-square cross-sectional approach can be used. Found prob value. of cross-section chi-square is 0.0000 so that the selected model is the fixed effect model. After having a fixed effect model, then it is then tested with the Hausman test with the following results:

Table 9. Hausman Test

\begin{tabular}{cccc}
\hline Test Summary & $\begin{array}{c}\text { Chi-Sq. } \\
\text { Statistics }\end{array}$ & Chi-Sq. df & Prob. \\
\hline Cross-section random & 2.687815 & 3 & 0.4423 \\
\hline
\end{tabular}

In determining the results of the Hausman test, a random cross-sectional approach was used. Found prob value. from a random crosssection with a value of 0.4423 so that the selected model is a random effect model. Therefore, the Lagrangian multiplier test is then used to determine the REM or CEM model.

Table 10. Lagrange Multiplier (LM) Test

\begin{tabular}{cccc}
\hline \multirow{2}{*}{ Test Summary } & $\begin{array}{c}\text { Cross-section } \\
\text { On-sided }\end{array}$ & $\begin{array}{c}\text { One-sided } \\
\text { period }\end{array}$ & \multirow{2}{*}{ Both } \\
\hline \multirow{2}{*}{ Breusch-Pagan } & 73.91095 & 0.380891 & 74.29184 \\
& $(0.0000)$ & $(0.5371)$ & $(0.0000)$ \\
\hline
\end{tabular}

In determining the results of the Lagrange multiplier test, the Breusch-Pagan approach is used. Found the value of prob. which is 0.0000 so that the selected model is a random effect model. The conclusion is that model A for economic growth and ICT uses a random effect model in the estimation of its value.

\subsection{Estimated Result}

In estimating each model has. In the classical assumption test, all models have passed the classical assumption for heteroscedasticity test and multicollinearity test.

The estimation results for model A are as follows.

Table 11. Model A . Estimation Data Panel

\begin{tabular}{ccccc}
\hline \multirow{2}{*}{ No. } & \multirow{2}{*}{ Variable } & Coefficient & Std. Error & Prob. \\
\cline { 3 - 5 } & & 11.87757 & 7.200449 & 0.1033 \\
\hline 1. & C & $1.75 \mathrm{E}-07$ & $1.26 \mathrm{E}-07$ & 0.1694 \\
3. & LLTE & $-1.68 \mathrm{E}-09$ & $2.34 \mathrm{E}-08$ & 0.9429 \\
3. & MOBP & -0.007265 & 0.041210 & 0.8605 \\
4. & INTU & $-5.40 \mathrm{E}-06$ & $4.64 \mathrm{E}-06$ & 0.2485 \\
5. & INSS & $1.71 \mathrm{E}-06$ & $3.26 \mathrm{E}-07$ & 0.0000 \\
6. & FIXB & 0.334341 & & \\
\hline & R-squared & 0.289364 & & \\
& Adjusted R-squared & 0.000011 & & \\
\hline
\end{tabular}

Note: Significant level $=5 \%$ 
The estimation results for model B are as follows.

Table 12. Panel Data Estimation Model B

\begin{tabular}{|c|c|c|c|c|}
\hline \multirow{2}{*}{ No. } & \multirow{2}{*}{ Variable } & \multicolumn{3}{|c|}{ Model B: Random Effect Model } \\
\hline & & Coefficient & Std. Error & Prob. \\
\hline 1. & $\mathrm{C}$ & 16.80256 & 4.539216 & 0.0004 \\
\hline 2 , & LLTE & $-7.73 E-08$ & $8.65 \mathrm{E}-08$ & 0.3749 \\
\hline 3. & MOBP & $-3.44 \mathrm{E}-08$ & $1.60 \mathrm{E}-08$ & 0.0347 \\
\hline 4. & INTU & -0.015923 & 0.028672 & 0.5803 \\
\hline 5. & INSS & $1.74 \mathrm{E}-06$ & $3.24 \mathrm{E}-06$ & 0.5927 \\
\hline 6. & FIXB & 7.21E-07 & 2.27E-07 & 0.0022 \\
\hline & R-squared & 0.203608 & & \\
\hline & Adjusted R-squared & 0.149797 & & \\
\hline & Prob(F-statistic) & 0.004172 & & \\
\hline
\end{tabular}

Note: Significant level $=5 \%$

The estimation results for model $\mathrm{B}$ are as follows.

Table 13. Model C. Data Estimation Panel

\begin{tabular}{|c|c|c|c|c|}
\hline \multirow{2}{*}{ No. } & \multirow{2}{*}{ Variable } & \multicolumn{3}{|c|}{ Model } \\
\hline & & Coefficient & Std. Error & Prob. \\
\hline 1. & $\mathrm{C}$ & 3.816640 & 1.133941 & 0.0012 \\
\hline 2 & TR & 0.052054 & 0.053804 & 0.3364 \\
\hline 3. & TRI & 0.045449 & 0.083893 & 0.5896 \\
\hline 4. & FDI & $6.31 \mathrm{E}-11$ & $2.68 \mathrm{E}-11$ & 0.0213 \\
\hline & R-squared & 0.100699 & & \\
\hline & Adjusted R-squared & 0.065201 & & \\
\hline & Prob(F-statistic) & 0.043620 & & \\
\hline
\end{tabular}

Note: Significant level $=5 \%$

The following is a hypothesis test for model B is as follows.

Table 14. Null Hypothesis

\begin{tabular}{|c|c|c|c|c|}
\hline No. & Null Hypothesis & coef. & Prob. & Effect \\
\hline \multicolumn{5}{|c|}{ Model A: Trade Export of ICT } \\
\hline 1. & LLTE & $1.75 \mathrm{E}-07$ & 0.1694 & Not significant \\
\hline 2. & MOBP & $-1.68 \mathrm{E}-09$ & 0.9429 & Not significant \\
\hline 3. & INTU & -0.007265 & 0.8605 & Not significant \\
\hline 4. & INSS & $-5.40 \mathrm{E}-06$ & 0.2485 & Not significant \\
\hline 5. & FIXB & $1.71 \mathrm{E}-06$ & 0.0000 & Significant \\
\hline \multicolumn{5}{|c|}{ Model B: Trade Import of ICT } \\
\hline 1. & LLTE & $-7.73 \mathrm{E}-08$ & 0.3749 & Not significant \\
\hline 2 , & MOBP & $-3.44 \mathrm{E}-08$ & 0.0347 & Significant \\
\hline 3. & INTU & -0.015923 & 0.5803 & Not significant \\
\hline 4. & INSS & $1.74 \mathrm{E}-06$ & 0.5927 & Not significant \\
\hline 5. & FIXB & $7.21 \mathrm{E}-07$ & 0.0022 & Significant \\
\hline \multicolumn{5}{|c|}{ Model C: Economic Growth and ICT } \\
\hline 1. & $\mathrm{TR}$ & 0.052054 & 0.3364 & Not significant \\
\hline 2. & TRI & 0.045449 & 0.5896 & Not significant \\
\hline 3. & FDI & $6.31 \mathrm{E}-11$ & 0.0213 & Significant \\
\hline
\end{tabular}

The table above shows hypothesis testing using a $95 \%$ confident interval (0.05) so that a number of variables will be significant when they have a prob value. $<0.05$. In model 1, it is found that only Fixed Broadband has a significant influence on ICT exports. In model 2 there are Mobile Phone and Fixed Boradband which have a significant influence on the import of ICT. While in model 3 only Foreign Direct Investment has a significant influence on economic growth.

\section{Conclusion}

Economic development in the world cannot be separated from the development of ICT which also contributes to economic growth. Until now, the measurement of economic growth is still one of the many approaches to see the performance of economic growth. Information Technology is a technology used to process data, including processing, obtaining, compiling, storing, manipulating data in various ways to produce quality information, namely information that is relevant, accurate, and timely, which is used for personal, business, governance, and is strategic information for decision making. Advances in information and communication technology have opened a new stage for people to obtain information autonomously. The information barriers automatically disappear by the strong initiative of individuals who want to know more about what is happening around them. People have access to information resources wherever they are. Consequently, society becomes critical and responsive to many things that develop.

From the research results, it is found that in model 1, it is found that only Fixed Broadband has a significant influence on ICT exports. When viewed from the role of fixed broadband in ICT, it is very important, considering that this information technology infrastructure is closely related to a number of other components such as internet access as well as cable development and data transmission. So in the export of ICT must consider the adequacy of infrastructure from fixed broadband in the country. In model 2 there are Mobile Phone and 
Fixed Boradband which have a significant influence on the import of ICT. This indicates that in importing ICT, the need for mobile phone components is negative, so that when ICT imports occur, the community's need for mobile phones will decrease. This is because the development of ICT is very rapid so that the mobile phone is not the only ICT device used. With the import of ICT, various components and ICT products will enter and compete with mobile phones. While in model 3 only Foreign Direct Investment has a significant influence on economic growth. It is undeniable that foreign direct investment is very important in relation to investment in a number of ICT projects in each country. Foreign direct investment can encourage economic growth from the availability of access to capital from abroad that can be invested in various strategic sectors that support macroeconomic growth. With the import of ICT, various components and ICT products will enter and compete with mobile phones. While in model 3 only Foreign Direct Investment has a significant influence on economic growth. It is undeniable that foreign direct investment is very important in relation to investment in a number of ICT projects in each country. Foreign direct investment can encourage economic growth from the availability of access to capital from abroad that can be invested in various strategic sectors that support macroeconomic growth. With the import of ICT, various components and ICT products will enter and compete with mobile phones. While in model 3 only Foreign Direct Investment has a significant influence on economic growth. It is undeniable that foreign direct investment is very important in relation to investment in a number of ICT projects in each country. Foreign direct investment can encourage economic growth from the availability of access to capital from abroad that can be invested in various strategic sectors that support macroeconomic growth. It is undeniable that foreign direct investment is very important in relation to investment in a number of ICT projects in each country. Foreign direct investment can encourage economic growth from the availability of access to capital from abroad that can be invested in various strategic sectors that support macroeconomic growth. It is undeniable that foreign direct investment is very important in relation to investment in a number of ICT projects in each country. Foreign direct investment can encourage economic growth from the availability of access to capital from abroad that can be invested in various strategic sectors that support macroeconomic growth.

The use of information technology in developing countries has grown rapidly and has entered various needs. Including in Indonesia, the use of sophisticated computer network technology has been designed since 2000 , when the use of computers became more and more evenly distributed. Local governments are increasingly showing a growing need for the use of ICT in order to make bureaucratic work more effective and efficient in serving the needs of the community. Bureaucratic work can indeed be simplified and shortened through the use of information technology. However, to get to the degree to develop the ability to use technology, of course, qualified human resources (HR) are needed. Therefore, for many developing countries, HR in the field of information technology must be properly prepared before replacing all lines of bureaucracy with information technology-based jobs. The role of ICT in community development can be framed in an open architecture model consisting of four different determinants. First, the social, economic and political structure. Second, the institution that initiated the ICT system, such as its role and the incentives provided. Third, the strategic behavior of the political elite that encourages the implementation of the IT system. Fourth, government policies, such as competition or monopolistic, foreign or domestic, central or decentralized. Second, the institution that initiated the ICT system, such as its role and the incentives provided. Third, the strategic behavior of the political elite that encourages the implementation of the IT system. Fourth, government policies, such as competition or monopolistic, foreign or domestic, central or decentralized. Second, the institution that initiated the ICT system, such as its role and the incentives provided. Third, the strategic behavior of the political elite that encourages the implementation of the IT system. Fourth, government policies, such as competition or monopolistic, foreign or domestic, central or decentralized.

\section{Acknowledgment}

We would like to thank the Faculty of Economics, Siliwangi University and the Capital Market Study Group (KSPM) of Siliwangi University in 2021 for supporting this research.

\section{References}

[1] M. F. Firmansyah, "Analisis Pertumbuhan Ekonomi Dalam Penentuan Basis Ekonomi, Isu Ketimpangan Dan Lingkungan Di Jawa Barat Periode 2010-2019," Jambura Econ. Educ. J., vol. 3, no. 1, pp. 8-27, 2021, doi: 10.37479/jeej.v3i1.8292.

[2] B. N. Adeleye, F. Adedoyin, and S. Nathaniel, "The criticality of ICT-trade nexus on economic and inclusive growth," Inf. Technol. Dev., vol. 27, no. 2, pp. 293-313, 2021, doi: 10.1080/02681102.2020.1840323.

[3] D. W. Jorgenson and K. Vu, "The ICT revolution, world economic growth, and policy issues," Telecomm. Policy, vol. 40, no. 5, pp. 383-397, 2016, doi: 10.1016/j.telpol.2016.01.002.

[4] T. Niebel, "ICT and economic growth - Comparing developing, emerging and developed countries," World Dev., vol. 104, no. 14, pp. 197-211, 2018, doi: 10.1016/j.worlddev.2017.11.024

[5] J. O. Ejemeyovwi, E. S. Osabuohien, and R. Osabohien, "ICT investments, human capital development and institutions in ECOWAS,” Int. J. Econ. Bus. Res., vol. 15, no. 4, pp. 463-474, 2018, doi: 10.1504/IJEBR.2018.092151.

[6] M. F. Firmansyah and F. Z. Nasution, "Indeks Kepuasan Publik Bidang Pariwisata dan Strategi Pengembangan Pariwisata di Wilayah Priangan Timur," Welf. J. Ilmu Ekon., vol. 6, no. 1, pp. 9-18, 2020.

[7] M. Murshed, "An empirical analysis of the non-linear impacts of ICT-trade openness on renewable energy transition, energy efficiency, clean cooking fuel access and environmental sustainability in South Asia," Environ. Sci. Pollut. Res., vol. 27, no. 29, pp. 36254-36281, 2020, doi: 10.1007/s11356-020-09497-3.

[8] M. F. Firmansyah, "Model Ekonomi Pengalaman: Memahami Perilaku Konsumen dan Layanan Konten Berbayar," J. Pemikir. Sosiol., vol. 7, no. 2, p. 152, 2020, doi: 10.22146/jps.v7i2.62530.

[9] M. W. Choirul Umam, F. Hardaningrum, and R. Durrotun Nasihien, "Analysis Of Traffic Accident Area On The Road In Gresik District Based On Geographic Information System,” Int. J. Eng. Sci. Inf. Technol., vol. 1, no. 2, 2021, doi: 10.52088/ijesty.v1i2.52.

[10] I. G. Dharma Utamayasa, "Efect Physical Activity and Nutrition During The Covid-19 Pandemic," Int. J. Eng. Sci. Inf. Technol., vol. 1, no. 1, 2021, doi: 10.52088/ijesty.v1i1.58.

[11] Z. Latif et al., "The dynamics of ICT, foreign direct investment, globalization and economic growth: Panel estimation robust to heterogeneity and cross-sectional dependence," Telemat. Informatics, vol. 35, no. 2, pp. 318-328, 2018, doi: 10.1016/j.tele.2017.12.006.

[12] S. Baqaruzi, A. Afit Miranto, and D. Wahyuda, "The Effect of Halbach Array Configuration on Permanent-Magnet Synchronous Generator (PMSG) Outer-Runner," Int. J. Eng. Sci. Inf. Technol., vol. 1, no. 2, 2021, doi: 10.52088/ijesty.v1i2.50.

[13] K. Saidi and C. Mongi, "The effect of education, R \& D and ICT on economic growth in high income countries," Econ. Bull., vol. 
38, no. 2, pp. 810-825, 2018.

[14] N. Adeleye and C. Eboagu, "Evaluation of ICT development and economic growth in Africa," NETNOMICS Econ. Res. Electron. Netw., 2019, doi: 10.1007/s11066-019-09131-6.

[15] M. M. Albiman and Z. Sulong, "The role of ICT use to the economic growth in Sub Saharan African region (SSA)," J. Sci. Technol. Policy Manag., vol. 7, no. 3, pp. 306-329, 2016, doi: 10.1108/JSTPM-06-2016-0010.

[16] A. A. Erumban and D. K. Das, "Information and communication technology and economic growth in India," Telecomm. Policy, vol. 40, no. 5, pp. 412-431, 2016, doi: 10.1016/j.telpol.2015.08.006.

[17] L. P. Nguyen and V. H. T. Pham, "Trade of ICT products, government, and economic growth: Evidence from East Asia-pacific region,” J. Asian Financ. Econ. Bus., vol. 7, no. 8, pp. 175-183, 2020, doi: 10.13106/JAFEB.2020.VOL7.NO8.175.

[18] N. W. Ismail and J. M. Mahyideen, The Impact of Infrastructure on Trade and Economic Growth in Selected Economies in Asia, no. 553. 2016

[19] R. Rinaldy and M. Ikhsan, "Determinant Analysis Of Conflict On Project Results In Aceh Province,” Int. J. Eng. Sci. Inf. Technol., vol. 1, no. 1, 2021, doi: 10.52088/ijesty.v1i1.37.

[20] D. Kumar, "Power System Restoration Using Multilayer Perceptron,” Int. J. Eng. Sci. Inf. Technol., vol. 1, no. 1, 2021, doi: 10.52088/ijesty.v1i1.35.

[21] B. Ozcan and H. K. Nath, "Department of Economics and International Business Working Paper No. 16-09 September 2016 INFORMATION AND COMMUNICATION TECHNOLOGY (ICT) AND INTERNATIONAL TRADE: EVIDENCE FROM TURKEY," no. 16, 2016, [Online]. Available: http://www.shsu.edu/academics/economics-and-internationalbusiness/documents/wp_series/wp16-09_paper.pdf.

[22] D. H. Sumitro, Ekonomi Pembangunan (Pengantar Ekonomi Pembangunan), no. 1. Tangerang Selatan: Unpam Press, 1992.

[23] H. C. Ukwuoma, "The Effect of ICT on Economic Growth in Nigeria," Int. J. Manag. Technol. Eng., vol. 9, no. 2, pp. 2292-2302, 2019.

[24] M. T. Majeed and T. Ayub, "Information and Communication Technology (ICT) and Economic Growth Nexus: A Comparative Global Analysis,” Pakistan J. Commer. Soc. Sci., vol. 12, no. 2, pp. 443-476, 2018.

[25] E. H. Nasab and M. Aghaei, "The Effect of ICT on Economic Growth: Further Evidence," Int. Bull. Bus. Adm., no. 5, pp. 47-56, 2009.

[26] Sudarno, Mustafid, and Z. B. Falah, "Model Regresi Data Panel Simultan,” vol. 5, pp. 611-621, 2016. 